\title{
Optimizing experimental simulation design for the emergency departments
}

\author{
Abdulkadir Atalan, Cem Cağrı Dönmez² \\ ${ }^{1}$ Gaziantep Islam Science and Technology University, Department of Industrial Engineering, Gaziantep, Turkey. \\ ${ }^{2}$ Marmara University, Department of Industrial Engineering, Istanbul, Turkey.
}

How to cite: Atalan, A., and Dönmez, C.C. (2020), “Optimizing experimental simulation design for the emergency departments", Brazilian Journal of Operations \& Production Management, Vol. 17, No. 4, e2020854. https://doi.org/10.14488/BJOPM.2020.026

\section{ABSTRACT}

Goal: this research aims to use the experimental simulation method is to obtain the optimum results by using the simulation technique of the models which are modeled mathematically but not solved.

Design/Methodology/Approach: a case study was conducted to apply discrete-event simulation (DES) approach based on design of experiment (DOE) technique to derive strategies and analyze situations in an emergency department (ED).

Results: by integrating the DOE approach with the DES technique for the ED, the average waiting time of a patient in a small ED was reduced from 40.09 minutes to 9.83 minutes $(75.48 \%)$, resulting in a significant result. The number of patients treated was increased from 132 to 147 (11.37\%) by increasing the capacity of resources without increasing the number of resources for ED in daily. Additionally, optimum the numbers of resources of the healthcare were calculated to employ in EDs.

Limitations of the investigation: there is no shift system for the resources of healthcare in the DES model. Since the ED was considered in this study, the same number of resources were run during the working hours of the DES model.

Practical implications: for researches and healthcare professionals, the developed method is used to provide the possibility of obtaining the results which cannot be obtained by mathematical modeling of the healthcare problems. The results of the changes made in health resources on the outputs are obtained by this method as the shortest and lowest cost.

Originality/Value: there is almost no detailed study of DES with DOE. Providing high reliability has resulted for the optimum values by integrating the DOE approach with the DES technique in healthcare area. It is very difficult to get accurate results everywhere where the human factor is.

Keywords: Discrete-event Simulation; Design of Experiment; Emergency Department; Resources of Healthcare.

\section{INTRODUCTION}

Nowadays, healthcare organizations have developed quality insights to better serve patients (Mosadeghrad, 2014). There are two main reasons for the systems of healthcare: increasing patient's satisfaction and reducing treatment costs (Dinh et al., 2012). A number of methods have been tried to reduce hospital costs and increase the satisfaction of patients, but the outcomes obtained are based on verbal and questionnaire results rather than numerical or computational results. In this study, DES with DOE approaches are examined and addressed to solve problems such as high waiting time and the length of stay (LOS), low the

Financial support: None

Conflic of interest: The authors have no conflict of interest to declare.

Corresponding author: abdulkadiratalan@gmail.com

Received: 9 May 2019.

Accepted: 7 May 2020.

Editor: Osvaldo L. G. Quelhas 
number patients treated, low satisfactions of patients, extraordinary cost of treatments, etc. for the ED (Atalan and Donmez, 2019).

Mostly, the methods developed are used to control costs and the number of patients treated by reducing the waiting time and the LOS of patients in ED (Salway et al., 2017; Plath et al., 2018). Simply, the LOS is equal to the sum of the waiting time and the treatment time of a patient. Thus, the cost of treatment is reduced in proportion to the decrease in the waiting time of patients. The existing resources in hospitals or EDs need to be managed properly to minimize the LOS and waiting time of patients (Atalan, 2020). However, a healthcare provider needs a long time to manage the resources within it. Because the number of ED's resources constitutes the number of combinations to create different scenarios. In a real situation, it is almost impossible to apply these combinations (Atalan, 2019). This problem can only be overcome by combining the DOE method and the DES technique. By combining these two methods, the best and tangible results be achieved in a very short time, which help to increase the best service for patients and reduce the cost of patient treatment in ED (Lin, 2008).

Healthcare structures have dynamic settings, multifaceted, and become large (Cabrera et al., 2011). Using DES and DOE techniques help to cope with these systems. All of healthcare providers such as government (state or public hospitals), private etc. try to reduce their expenses, idle resources which are physicians, nurses, exam rooms, administrators, etc., increase their performance, and minimize patient waiting time. However, changing resources of hospital or ED obviously takes long time and very costly without using DES and DOE. With the experimental design and optimization DES technique, a 28\% increase in patient outcomes and a $40 \%$ decrease in patient waiting time were thought to be due to optimum staff management among the most notable findings in terms of research (Ahmed and Alkhamis, 2009).

Many companies have generally needed to use DES in a wide range of area (Bates et al., 2006). The reason behind that is the advantages the computer DES obtains such as saving time, cost and changing resources easily for the industry. Especially, the healthcare area has spent much time to apply DES model in their facilities in order to improve resources' capacity. However, using only DES is not enough to get accurate results in healthcare area because of human factor. In the past, some researchers have tried some applications to a DES model. These applications, conventional design methods, intent to improve the performances of goods (Park et al., 2006). However, these situations may not be valid to get healthy results. The main problems in many industrial environments to improve the quality of product and performances are the necessity to succeed a target value and intercept a small variance (Ding et al., 2004).

\section{Object of The Study}

We offered a new concept of DOE contains simulation experiment which utilizes the DOE. This paper is different from other studies; is that the scenarios of optimization models (problems that are difficult to resolve) are derived from the DES technique, but the optimization models need to be created in accordance with the information obtained as a result of the experimental design. Because, how the factors affect the response cannot be determined without experimental design. Furthermore, it is very difficult to control by DES how to determine how only the factors will affect the response, not the individual, but the interaction with each other factor. Generated and gathered data from the DES of the Flexsim Healthcare model (simulation software is used in this study), which was chosen to model this DES because of its ease of use, for the DOE was optimized in Minitab Statistic Software which is used in the academic and industry area by researchers and companies to compare outcomes from these tools in order to display the results are accurate. 


\section{LITERATURE REVIEW}

\section{Overview of DES Applications}

The use of the DES technique is based on the 1960s. This technique has been developed due to the need to gain time and cost loss. The first application was made in the maritime sector, which was an oil carrier in the 1962s (Buxton and Laski, 1962; Pidd, 2004). The literature shows that the areas where the DES technique is used vary until nowadays. The basic rules of the DES method are quite simple. The person who will create the DES model first builds the model of the system it is interested in, writes the computer program of the DES model (if there is no preset program), and executes the DES model by making the changes that it wishes to make (Günal and Pidd, 2010; Atalan, 2014).

Correct design of simulation experiments is a good technique to provide effective ways of estimating the effects of the DES model on the responses of inputs (Kelton and Barton, 2003). Computer DES methodology, involving large statistics information in order to have rational answers by data, is one of the most prevalent tools for quality engineering systems. DES operates complex variables and constraints to describe a system strictly (Montevechi et al., 2007). Furthermore, forecasting performances of systems, DES likewise empowers projecting for future. The DES model contributes a healthier understanding of the probable performance of the actual system if it is run precisely (Barton, 2001). As an analytical technique, DES embraces systems and models of those systems (Kelton, 2004). DES models usually have many input factors and it is difficult to determine which of them is a significant influence on the responses in healthcare area (Law, 2014). The use of DOE with DES allow a better-organized analysis of the results from the DES model to carry out decision-making.

The most significant constraint for using the DES method is; how complicated the system is (Unwin et al., 2016). If the variables affecting the system are so many and interact with each other, it will be very beneficial to use the DES technique. In summary, it is inevitable to use the DES for the subjects such as for systems that are costly and time-consuming to change resources, very difficult to develop a mathematical model, the system has many response, dependent and independent variables (factors), examination of the DES model in a certain time period (especially in healthcare), to have visuals and animation are needed, to understand how the system's resources change and how the response varies (Atalan, 2018).

\section{Overview of Design of Experiment}

The idea of experiment design was first presented by Dr. Fisher in 1920s at the Rothamsted Agricultural Field Research laboratory in London, England. Fisher wrote a book related to statistical methods for use in laboratory studies for researchers (Fisher, 1971).

DOE is generally an effective statistical method used to gain knowledge of variation in the products or services, improve process performance or product quality. The DOE consists of four steps. These are: are: planning, designing, conducting, analyzing are occupied yourself important roles in statistical methods (Antony, 2003). By applying these steps with obtaining accurate data in the $\mathrm{DOE}$, it is ensured that a process performance or quality of a product are supplied. Additionally, application of DOE provides to reduce the variation in the products and services.

In the experiments conducted in the production companies, most of the engineers analyze one of the factors affecting the product while keeping the others stable (Eriksson et al., 2001). This approach provides limited knowledge about product quality. The results obtained are ineffective, unreasonable, time-consuming and inaccurate optimum conditions for products and processes (Myers et al., 2016). However, there are different factors in producing each product and different levels for each factor that analyze by DOE. Some factors strongly influence responses, while others affect response at least. One of the advantages of the DOE application is to make the changes in the factors used for the designed experiments and to measure the effect on the response variables. 
In this study, full-factorial multi-level design was considered, and the data analyzed in DOE was generated. Thus, factors were calculated not only singly but also interactively with their significance levels. The reason for this is that the presence of multi-objective functions has shown a stochastic structure in the model to be created (Deb and Kalyanmoy, 2001). Multi-objective complications comprise many restrictions may not able to be answered itself inadequate DOE beside DES (Baesler and Sepúlveda, 2001). DOE approach and DES technique were identified to assess the effects of the constraints and its interfaces particularized in the process.

Overall, the application of DOE provides the quality of services precisely, accurately, and with stability in the healthcare area. It is easy to changes the resources of healthcare (input variables) to understand how the responses' performances (waiting time and patient output) varies consequently. Another advantages of application of DOE is to gain information widely about all dimensions of the objective functions and input-output associations. Reducing the variability of factors from their optimum values protect to lead to problems such as high treatment cost and patient's waiting time, low the number of patients treated, etc.

\section{RESEARCH METHOD}

\section{Establishment of DES Model}

The records were composed of averages based on other raw data findings. These averages derived from many dissimilar references and generated a precise distribution for a computer DES model. A large amount of data gathered from studies demonstrated to be more beneficial than the beforehand found means. By using the DES models of any part of a hospital, the detailed statistical information of that part is obtained. The ED of a small hospital that are considered for this study activates around the clock (Altiok and Melamed, 2007). It is operated by two clerks at the reception office, and three medical doctors on the locations, supported by three nurses to treat the patients at the triage areas and exam rooms. The department of the ED has two triage sections for the nurses to serve patients. When the model runs, the result data thoroughly match the actual real data that is collected. This is the fundamental model and is being used to show the great potential of modeling software being used in the experimental throughput analysis (see Figure 1).

General, the averages were used to compute a distribution exhibiting of the number of people who arrived at hospital. Due to the nature of this portion of information, it was not as authoritative to contract data beyond the average. Using means from the various sources, an average patient entrance rate, number of resources was decided upon. The other activity distributions derived from the data collected from reports and researches. Data evaluation software (Expert fit Analyzer in Flexsim HC) was used to analyze the raw data verified in the resources. Each of the time periods registered above are procedures that some patient requirements to go through while they are in the ED. Each of these routes proceeds an average amount of time, with a certain distribution. Using data analysis software accurately simulated the various processes that occur when a patient goes to a clinic. Figure 2 represents a plan of the patient flow diagram for ED in the part of a hospital, from arrival to release. 


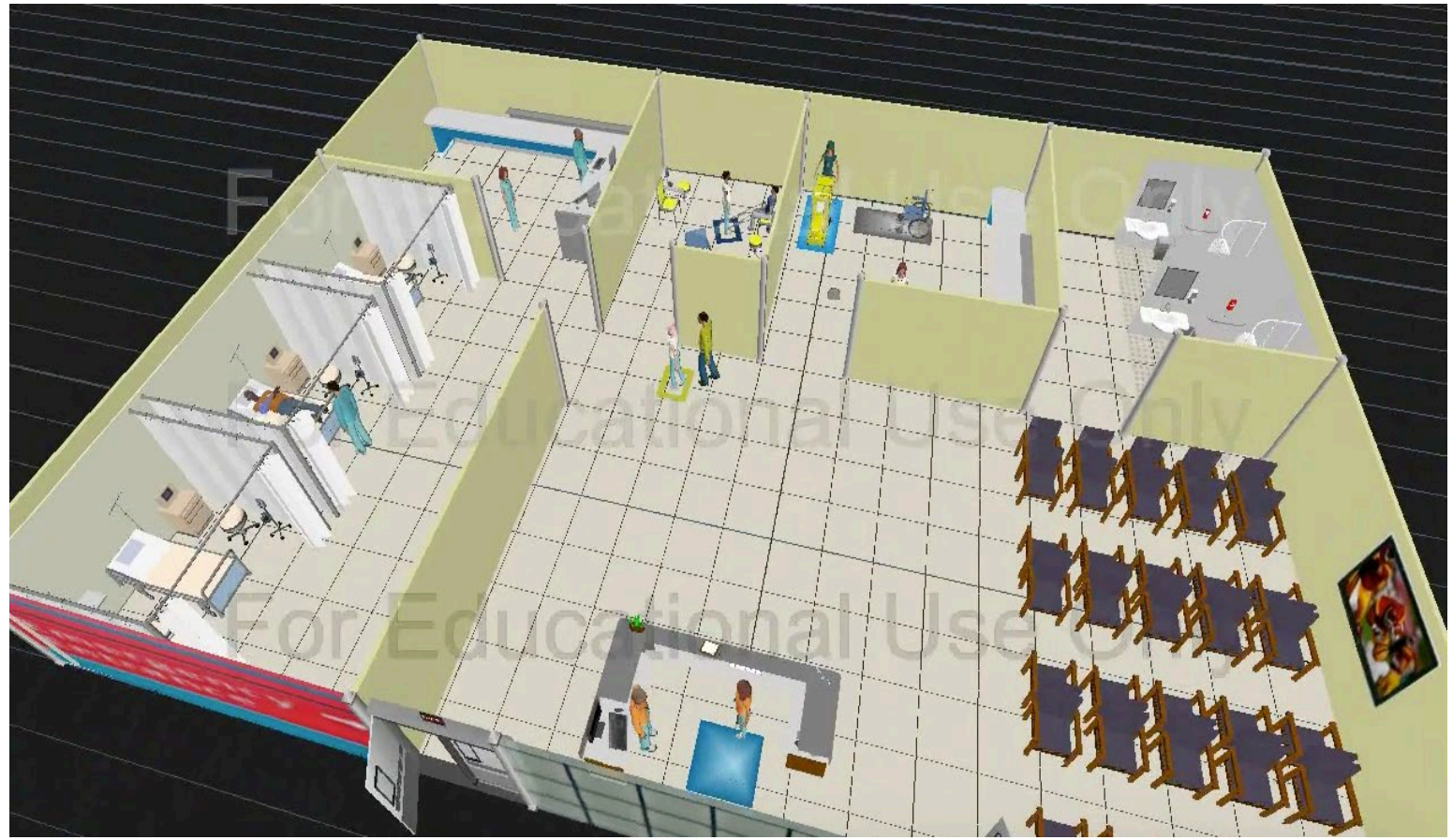

Figure 1. DES model screen view

The preconditions of the DES model;

* No division of work shifts of resources of the ED (no needed resources scheduling),

* A 24-hour healthcare service period,

* Patients have two options to get treatment by physicians or nurses (after the treatment process, the patients leave from the ED or register for the policlinic),

* After every process, the patients go to waiting room to wait the next process (otherwise, there will be queues where there are transactions, and the next patient will not benefit from the process),

* The same resources may have different process times for patients (such as triage and treatment processes time by nurses),

* The same resources can do two different processes at different times (such as check-in and check-out),

* The system works with the principle that the first in (come)-first treatment (out) (FIFO FIFT).

* The FIFT principle is not applicable to acute patients.

The patient flow situation in the hospital is as follows: the patient arriving at the hospital is registered first. The registered patient is treated by the nurse in triage section for preliminary diagnosis. Depending on the urgency of the patient, they can either contact the doctor immediately or the patient waits according to the availability of the doctor. Once the doctor has treated the patient, the patient checks out and leaves the hospital or registers for the polyclinic. 


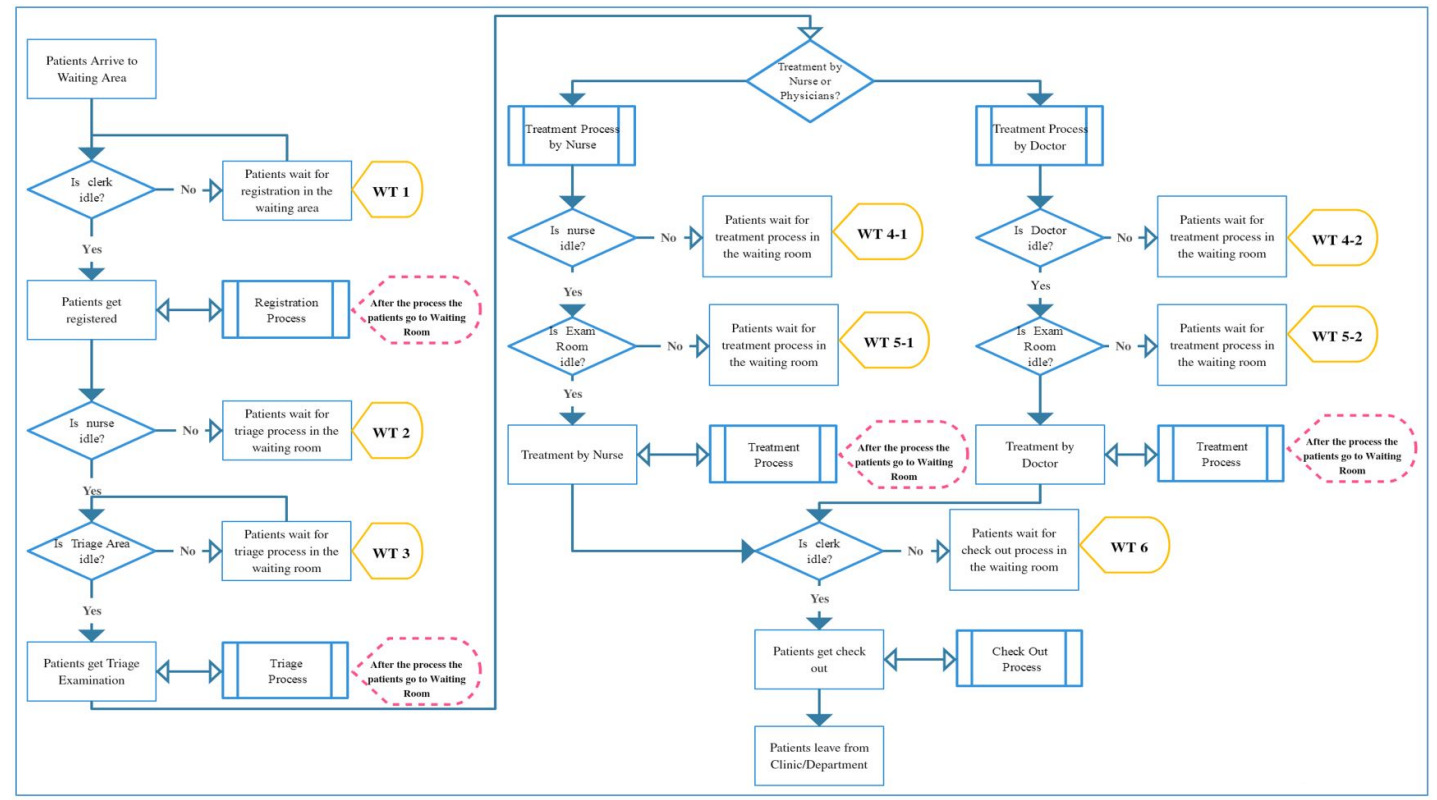

Figure 2. The flowchart of the patient flow in the ED

\section{Establishment of DOE}

DOE involves a set of mathematical and statistical methods expended in the development of an acceptable functional affiliation between a response of relevance, $y$, and a number of linked control (or input) variables symbolized by $x_{1}, x_{2}, \ldots, x_{k}$ or $A, B, \ldots, N$ (Khuri and Mukhopadhyay, 2010). The essential idea is to appropriate a model for the response variable and then investigate various settings of interest for the descriptive variables (Ding et al., 2004).

DOE usually includes the first-order (Oehlert, 2010) and the multiple linear equations. On the basis of these equations, the response values obtained from the factors are revealed. If there is no interaction between the factors, the first-order equation is obtained. With the interaction between the factors, the multiple linear equations occur at the first-order. Optimization models of the multiple linear equations are more difficult to solve. The purpose of multiple regression is to use simultaneous use of a set of predictive variables (Hoyt et al., 2014). In this research, both the existence of linear and multiple linear equations and the fact that the decision variables included in the optimization model are integers make the solution of the problem more complex.

In this study, the experiment is a full factorial multi-level design that has five experimental variables: physicians, nurses, clerks, triage rooms, and exam rooms, and each factor has different level with two replicated on each design combination. The experimental conditions are displayed in Table 1. According to DOE, we run our experiment in 216 times which is our total scenario for the DES model in a short time. In actual life, it seems impossible to apply this amount of runs presently.

Table 1 Conditions and scenarios of the resources of ED

\begin{tabular}{ccccccccc}
\hline Factors & Index & Level $^{\mathbf{1}}$ & Level $^{\mathbf{2}}$ & Level $^{\mathbf{3}}$ & Scenario $^{\mathbf{1}}$ & Scenario $^{\mathbf{2}}$ & $\ldots$ & Scenario $^{\mathbf{2 1 6}}$ \\
\hline Number of Physicians & $\mathrm{P}$ & 1.00 & 2.00 & 3.00 & 1.00 & 1.00 & $\ldots$ & 3.00 \\
\hline Number of Nurses & $\mathrm{N}$ & 1.00 & 2.00 & 3.00 & 2.00 & 3.00 & $\ldots$ & 3.00 \\
Number of Clerks & $\mathrm{C}$ & 1.00 & 2.00 & 0.00 & 2.00 & 3.00 & $\ldots$ & 2.00 \\
\hline $\begin{array}{c}\text { Number of Triage } \\
\begin{array}{c}\text { Rooms } \\
\text { Number of Exam }\end{array}\end{array}$ & $\mathrm{T}$ & 1.00 & 2.00 & 0.00 & 3.00 & 2.00 & $\ldots$ & 2.00 \\
\hline $\begin{array}{c}\text { Rooms } \\
\text { ER }\end{array}$ & 1.00 & 2.00 & 3.00 & 3.00 & 2.00 & $\ldots$ & 3.00 \\
\hline
\end{tabular}


The steps of the DES model with different states are explained in detail in Table 2 . According to this table, there are 262,144 ( $4 \times 8 \times 4 \times 8 \times 8 \times 8 \times 8 \times 4$ ) scenarios of the constraints created to obtain the objective functions of the study.

Table 2. Steps of the patients flow under the different scenarios

\begin{tabular}{|c|c|c|c|c|c|c|}
\hline \multicolumn{7}{|c|}{ STEP 1: Check-in Process by Clerks } \\
\hline Scenarios & $\begin{array}{l}\text { Treatment } \\
\text { Time }\end{array}$ & $\begin{array}{l}\text { Waiting } \\
\text { Time }\end{array}$ & Busy & Idle & Comments & Constraints \\
\hline 1 & 0 & 0 & * & $c_{1}, c_{2}$ & $\begin{array}{l}\text { The clerks are idle because } \\
\text { there are no patients. }\end{array}$ & $x_{c}=2$ \\
\hline 2 & $t_{c l}$ & 0 & $c_{1}$ & $c_{2}$ & $\begin{array}{l}\text { When a clerk checks in or checks } \\
\text { out, the other clerk is idle. }\end{array}$ & $x_{c}=1$ \\
\hline 3 & $t_{c 2}$ & 0 & $c_{2}$ & $c_{1}$ & $\begin{array}{c}\text { When a clerk checks in or checks } \\
\text { out, the other clerk is idle. }\end{array}$ & $x_{c}=1$ \\
\hline 4 & $\left(t_{c 1}, t_{c 2}\right)$ & $\min \left\{t_{c 1}, t_{c 2}\right\}$ & $c_{1}, c_{2}$ & * & $\begin{array}{l}\text { Both clerks can check in or check } \\
\text { out. The patients must wait. }\end{array}$ & $x_{c}=0$ \\
\hline \multicolumn{7}{|c|}{ STEP $2{ }_{1}$ : Triage Process } \\
\hline Scenarios & $\begin{array}{l}\text { Treatment } \\
\text { Time }\end{array}$ & $\begin{array}{l}\text { Waiting } \\
\text { Time }\end{array}$ & Busy & Idle & Comments & Constraints \\
\hline 1 & 0 & 0 & * & $n_{1}, n_{2}, n_{3}$ & $\begin{array}{c}\text { All nurses and triage areas are } \\
\text { idle for triage }\end{array}$ & $x_{n}=3$ and $x_{t}=2$ \\
\hline 2 & $t_{n 1}$ & 0 & $n_{l}$ & $n_{2}, n_{3}$ & $\begin{array}{l}\text { Only one nurse is doing triage. } \\
\text { The other nurses are waiting. }\end{array}$ & $x_{n}=2$ and $x_{t}=2$ \\
\hline 3 & $t_{n 2}$ & 0 & $n_{2}$ & $n_{1}, n_{3}$ & $\begin{array}{l}\text { Only one nurse is doing triage. } \\
\text { The other nurses are waiting. }\end{array}$ & $x_{n}=2$ and $x_{t}=2$ \\
\hline 4 & $t_{n 3}$ & 0 & $n_{3}$ & $n_{1}, n_{2}$ & $\begin{array}{l}\text { Only one nurse is doing triage. } \\
\text { The other nurses are waiting. }\end{array}$ & $x_{n}=2$ and $x_{t}=2$ \\
\hline 5 & $t_{n 4}$ & 0 & $n_{1}, n_{2}$ & $n_{3}$ & $\begin{array}{c}\text { Two nurses are working. } \\
\text { A nurse is waiting for triage or } \\
\text { treatment. }\end{array}$ & $\begin{array}{c}x_{n}=1 \text { and } x_{t}=2 \\
\text { and } x_{e}=3\end{array}$ \\
\hline 6 & $t_{n 5}$ & 0 & $n_{1}, n_{3}$ & $n_{2}$ & $\begin{array}{c}\text { Two nurses are working. } \\
\text { A nurse is waiting for triage or } \\
\text { treatment. }\end{array}$ & $\begin{array}{c}x_{n}=1 \text { and } x_{t}=2 \\
\text { and } x_{e}=3\end{array}$ \\
\hline 7 & $t_{n 6}$ & 0 & $n_{2}, n_{3}$ & $n_{l}$ & $\begin{array}{l}\text { Two nurses are working. } \\
\text { A nurse is waiting for triage or } \\
\text { treatment. }\end{array}$ & $\begin{array}{c}x_{n}=1 \text { and } x_{t}=2 \\
\text { and } x_{e}=3\end{array}$ \\
\hline 8 & $\begin{array}{l}t_{n 1}, t_{n 2}, t_{n 3} \\
t_{n 4}, t_{n 5}, t_{n 6}\end{array}$ & $\begin{array}{l}\min \left\{t_{n 1}, t_{n 2}, t_{n 3},\right. \\
\left.t_{n 4}, t_{n 5}, t_{n 6}\right\}\end{array}$ & $n_{1}, n_{2}, n_{3}$ & * & $\begin{array}{l}\text { All nurses either treat or triage. } \\
\text { The patients must wait. }\end{array}$ & $\begin{array}{c}x_{n}=0 \text { and } x_{t}=2 \\
\text { and } x_{e}=0\end{array}$ \\
\hline \multicolumn{7}{|c|}{ STEP $2_{2}:$ Triage Process in the Triage Area } \\
\hline Scenarios & $\begin{array}{l}\text { Treatment } \\
\text { Time }\end{array}$ & $\begin{array}{l}\text { Waiting } \\
\text { Time }\end{array}$ & Busy & Idle & Comments & Constraints \\
\hline 1 & 0 & 0 & * & $t_{1}, t_{2}$ & $\begin{array}{l}\text { The triages are idle because } \\
\text { there are no patients. }\end{array}$ & $x_{t}=2$ \\
\hline 2 & $t_{n 1}, t_{n 2}, t_{n 3}$ & 0 & $t_{1}$ & $t_{2}$ & $\begin{array}{c}\text { When a triage is busy, the other } \\
\text { triage is idle. }\end{array}$ & $x_{t}=1$ and $x_{n} \leq 2$ \\
\hline 3 & $t_{n 1}, t_{n 2}, t_{n 3}$ & 0 & $t_{2}$ & $t_{l}$ & $\begin{array}{c}\text { When a triage is busy, the other } \\
\text { triage is idle. }\end{array}$ & $x_{t}=1$ and $x_{n} \leq 2$ \\
\hline 4 & $\begin{array}{l}\left(t_{n 1}, t_{n 2}\right) \\
\left(t_{n 1}, t_{n 3}\right) \\
\left(t_{n 2}, t_{n 3}\right)\end{array}$ & $\begin{array}{l}\min \left\{t_{n 1}, t_{n 2}, t_{n 3},\right. \\
\left.t_{n 4}, t_{n 5}, t_{n 6}\right\}\end{array}$ & $t_{1}, t_{2}$ & * & $\begin{array}{l}\text { Both triage areas are busy. } \\
\text { The patients must wait. }\end{array}$ & $x_{n}=0$ and $x_{n}=2$ \\
\hline
\end{tabular}


Table 2. Continued...

STEP 31: Treatment Process by Physicians

\begin{tabular}{|c|c|c|c|c|c|c|}
\hline Scenarios & $\begin{array}{l}\text { Treatment } \\
\text { Time }\end{array}$ & $\begin{array}{l}\text { Waiting } \\
\text { Time }\end{array}$ & Busy & Idle & Comments & Constraints \\
\hline 1 & 0 & 0 & * & $p_{1}, p_{2}, p_{3}$ & $\begin{array}{l}\text { All physicians are idle for } \\
\text { treatments }\end{array}$ & $x_{p}=3$ \\
\hline 2 & $t_{p 1}$ & 0 & $p_{1}$ & $p_{2}, p_{3}$ & $\begin{array}{l}\text { Only one physician is in the } \\
\text { process of treatment. } \\
\text { The others are waiting. }\end{array}$ & $x_{p}=2$ and $x_{e} \leq 3$ \\
\hline 3 & $t_{p 2}$ & 0 & $p_{2}$ & $p_{1}, p_{3}$ & $\begin{array}{l}\text { Only one physician is in the } \\
\text { process of treatment. } \\
\text { The others are waiting. }\end{array}$ & $x_{p}=2$ and $x_{e} \leq 3$ \\
\hline 4 & $t_{p 3}$ & 0 & $p_{3}$ & $p_{1}, p_{2}$ & $\begin{array}{l}\text { Only one physician is in the } \\
\text { process of treatment. } \\
\text { The others are waiting. }\end{array}$ & $x_{p}=2$ and $x_{e} \leq 3$ \\
\hline 5 & $t_{p 4}$ & 0 & $p_{1}, p_{2}$ & $p_{3}$ & $\begin{array}{l}\text { Two physicians are working. } \\
\text { A physician is waiting for } \\
\text { treatment. }\end{array}$ & $x_{p}=1$ and $x_{e} \leq 3$ \\
\hline 6 & $t_{p 5}$ & 0 & $p_{1}, p_{3}$ & $p_{2}$ & $\begin{array}{l}\text { Two physicians are working. } \\
\text { A physician is waiting for } \\
\text { treatment. }\end{array}$ & $x_{p}=1$ and $x_{e} \leq 3$ \\
\hline 7 & $t_{p 6}$ & 0 & $p_{2}, p_{3}$ & $p_{l}$ & $\begin{array}{l}\text { Two physicians are working. } \\
\text { A physician is waiting for } \\
\text { treatment. }\end{array}$ & $x_{p}=1$ and $x_{e} \leq 3$ \\
\hline 8 & $\begin{array}{l}t_{p 1}, t_{p 2}, t_{p 3} \\
t_{p 4}, t_{p 5}, t_{p 6}\end{array}$ & $\begin{array}{l}\min \left\{t_{p 1}, t_{p 2}, t_{p 3},\right. \\
\left.t_{p 4}, t_{p 5}, t_{p 6}\right\}\end{array}$ & $p_{1}, p_{2}, p_{3}$ & * & $\begin{array}{l}\text { All Physicians treat the patients. } \\
\text { The patients have to wait. }\end{array}$ & $x_{p}=0$ and $x_{e}=3$ \\
\hline
\end{tabular}

STEP $3_{2}$ : Treatment Process by Nurses

\begin{tabular}{|c|c|c|c|c|c|c|}
\hline Scenarios & $\begin{array}{l}\text { Treatment } \\
\text { Time }\end{array}$ & $\begin{array}{l}\text { Waiting } \\
\text { Time }\end{array}$ & Busy & Idle & Comments & Constraints \\
\hline 1 & 0 & 0 & * & $n_{1}, n_{2}, n_{3}$ & $\begin{array}{l}\text { All Nurses are idle for } \\
\text { treatments }\end{array}$ & $x_{n}=3$ \\
\hline 2 & $t_{n 1}$ & 0 & $n_{l}$ & $n_{2}, n_{3}$ & $\begin{array}{l}\text { Only one nurse is doing } \\
\text { treatment. The other nurses are } \\
\text { waiting. }\end{array}$ & $\begin{array}{l}x_{n}=2 \text { and } x_{e} \leq \\
3 \text { or } x_{t}=2\end{array}$ \\
\hline 3 & $t_{n 2}$ & 0 & $n_{2}$ & $n_{l}, n_{3}$ & $\begin{array}{l}\text { Only one nurse is doing } \\
\text { treatment. The other nurses are } \\
\text { waiting. }\end{array}$ & $\begin{array}{l}x_{n}=2 \text { and } x_{e} \leq \\
3 \text { or } x_{t}=2\end{array}$ \\
\hline 4 & $t_{n 3}$ & 0 & $n_{3}$ & $n_{1}, n_{2}$ & $\begin{array}{l}\text { Only one nurse is doing } \\
\text { treatment. The other nurses are } \\
\text { waiting. }\end{array}$ & $x_{n}=2$ \\
\hline 5 & $t_{n 4}$ & 0 & $n_{1}, n_{2}$ & $n_{3}$ & $\begin{array}{c}\text { Two nurses are working. } \\
\text { A nurse is waiting for triage or } \\
\text { treatment. }\end{array}$ & $x_{n}=1$ \\
\hline 6 & $t_{n 5}$ & 0 & $n_{1}, n_{3}$ & $n_{2}$ & $\begin{array}{l}\text { Two nurses are working. } \\
\text { A nurse is waiting for triage or } \\
\text { treatment. }\end{array}$ & $x_{n}=1$ \\
\hline 7 & $t_{n 6}$ & 0 & $n_{2}, n_{3}$ & $n_{l}$ & $\begin{array}{l}\text { Two nurses are working. } \\
\text { A nurse is waiting for triage or } \\
\text { treatment. }\end{array}$ & $x_{n}=1$ \\
\hline 8 & $\begin{array}{l}t_{n 1}, t_{n 2}, t_{n 3} \\
t_{n 4}, t_{n 5}, t_{n 6}\end{array}$ & $\begin{array}{l}\min \left\{t_{n 1}, t_{n 2}, t_{n 3}\right. \\
\left.t_{n 4}, t_{n 5}, t_{n 6}\right\}\end{array}$ & $n_{1}, n_{2}, n_{3}$ & * & $\begin{array}{c}\text { All nurses either treat or triage. } \\
\text { The patients must wait. }\end{array}$ & $x_{n}=0$ \\
\hline
\end{tabular}


Table 2. Continued...

\begin{tabular}{|c|c|c|c|c|c|c|}
\hline \multicolumn{7}{|c|}{ STEP $3_{3}$ : Treatment Process in the Exam Rooms } \\
\hline Scenarios & $\begin{array}{l}\text { Treatment } \\
\text { Time }\end{array}$ & $\begin{array}{l}\text { Waiting } \\
\text { Time }\end{array}$ & Busy & Idle & Comments & Constraints \\
\hline 1 & 0 & 0 & * & $e_{1}, e_{2}, e_{3}$ & $\begin{array}{l}\text { All Exam Rooms are idle for } \\
\text { treatment }\end{array}$ & $x_{e}=3$ \\
\hline 2 & $t_{e l}$ & 0 & $e_{1}$ & $e_{2}, e_{3}$ & $\begin{array}{l}\text { Treatment is done in one exam } \\
\text { room only. The others are idle. }\end{array}$ & $\begin{array}{l}x_{e}=2 \text { and } x_{n} \leq \\
2 \text { or } x_{p} \leq 2\end{array}$ \\
\hline 3 & $t_{e 2}$ & 0 & $e_{2}$ & $e_{1}, e_{3}$ & $\begin{array}{l}\text { Treatment is done in one exam } \\
\text { room only. The others are idle. }\end{array}$ & $\begin{array}{l}x_{e}=2 \text { and } x_{n} \leq \\
2 \text { or } x_{p} \leq 2\end{array}$ \\
\hline 4 & $t_{e 3}$ & 0 & $e_{3}$ & $e_{1}, e_{2}$ & $\begin{array}{l}\text { Treatment is done in one exam } \\
\text { room only. The others are idle. }\end{array}$ & $\begin{array}{l}x_{e}=2 \text { and } x_{n} \leq \\
2 \text { or } x_{p} \leq 2\end{array}$ \\
\hline 5 & $t_{e 4}$ & 0 & $e_{1}, e_{2}$ & $e_{3}$ & $\begin{array}{l}\text { Two exam rooms are used for } \\
\text { treatment. An exam room is } \\
\text { idle. }\end{array}$ & $\begin{array}{l}x_{e}=1 \text { and } x_{n} \leq \\
\text { lor } x_{p} \leq 1\end{array}$ \\
\hline 6 & $t_{e 5}$ & 0 & $e_{1}, e_{3}$ & $e_{2}$ & $\begin{array}{l}\text { Two exam rooms are used for } \\
\text { treatment. An exam room is } \\
\text { idle. }\end{array}$ & $\begin{array}{l}x_{e}=1 \text { and } x_{n} \leq \\
\operatorname{lor} x_{p} \leq 1\end{array}$ \\
\hline 7 & $t_{e 6}$ & 0 & $e_{2}, e_{3}$ & $e_{1}$ & $\begin{array}{l}\text { Two exam rooms are used for } \\
\text { treatment. An exam room is } \\
\text { idle. }\end{array}$ & $\begin{array}{l}x_{e}=\operatorname{land} x_{n} \leq \\
\operatorname{lor} x_{p} \leq 1\end{array}$ \\
\hline 8 & $\begin{array}{l}t_{e 1}, t_{e 2}, t_{e 3} \\
t_{e 4}, t_{e 5}, t_{e 6}\end{array}$ & $\begin{array}{l}\min \left\{t_{e l}, t_{e 2}, t_{e 3},\right. \\
\left.t_{e 4}, t_{e s}, t_{e 6}\right\}\end{array}$ & $e_{1}, e_{2}, e_{3}$ & * & $\begin{array}{l}\text { All nurses either treat or triage. } \\
\text { The patients must wait. }\end{array}$ & $\begin{array}{l}x_{e}=0 \text { and } x_{n} \leq \\
3 \text { or } x_{p} \leq 3\end{array}$ \\
\hline \multicolumn{7}{|c|}{ STEP 4: Check-out Process by Clerks } \\
\hline Scenarios & $\begin{array}{l}\text { Treatment } \\
\text { Time }\end{array}$ & $\begin{array}{l}\text { Waiting } \\
\text { Time }\end{array}$ & Busy & Idle & Comments & Constraints \\
\hline 1 & 0 & 0 & * & $c_{1}, c_{2}$ & $\begin{array}{l}\text { The clerks are idle because } \\
\text { there are no patients. }\end{array}$ & $x_{c}=2$ \\
\hline 2 & $t_{c l}$ & 0 & $c_{l}$ & $c_{2}$ & $\begin{array}{l}\text { When a clerk checks in or } \\
\text { checks out, the other clerk is } \\
\text { idle. }\end{array}$ & $x_{c}=1$ \\
\hline 3 & $t_{c 2}$ & 0 & $c_{2}$ & $c_{1}$ & $\begin{array}{l}\text { When a clerk checks in or } \\
\text { checks out, the other clerk is } \\
\text { idle. }\end{array}$ & $x_{c}=1$ \\
\hline 4 & $\left(t_{c 1}, t_{c 2}\right)$ & $\min \left\{t_{c l}, t_{c 2}\right\}$ & $c_{1}, c_{2}$ & * & $\begin{array}{l}\text { Both clerks can check in or } \\
\text { check out. The patients must } \\
\text { wait. }\end{array}$ & $x_{c}=0$ \\
\hline
\end{tabular}

$c_{1}, c_{2}:$ Clerk 1 and Clerk 2,

${ } n_{1}, n_{2}, n_{3}: \quad$ Nurse 1, Nurse 2, and Nurse 3,

- $p_{1}, p_{2}, p_{3}$ : Physician 1, Physician 2, and Physician 3,

- $e_{1}, e_{2}, e_{3}$ Exam Room 1, Exam Room 2, and Exam Room 3,

$\cdot t_{1}, t_{2}$ : Triage 1 and Triage 2 ,

- $t_{n 1}, t_{n 2}, t_{n 3}, t_{n 4}, t_{n 5}, t_{n 6}$ : The time required for the patient to wait until nurses are idle,

- $t_{p 1}, t_{p 2}, t_{p 3}, t_{p 4}, t_{p 5}, t_{p 6}: \quad$ The time required for the patient to wait until physicians are idle,

- $t_{e 1}, t_{e 2}, t_{e 3}, t_{e 4}, t_{e 5}, t_{e 6}: \quad$ The time required for the patient to wait until exam rooms are idle,

- $x_{i}$ : The numbers of resources are busy or idle, $i=\{p, n, e r, t, c\}$, 


\section{RESULTS AND DISCUSSIONS}

Each scenario's detail result is provided by the DES application that shows understanding of the possible performance of the system. Both results of DES and DOE demonstrate that controllable factors which are physicians, nurses, exam rooms, triage chairs, and clerks more effectively impact on the clinic's performance. Two types of data have been considered after the DES and DOE. The first results are related to the total number of patients being treated and the second is related to the waiting times of the patients in the hospital.

As a result of statistical analysis, the number of doctors, nurses, and exam rooms directly affect the total number of patients treated. In particular, the number of triages appears to have not had much effect on the number of patients treated. However, it is shown in Table 3 that these factors influence the number of patients treated at an important level with the interaction. These results are also found to have the same effect on the waiting times that patients are exposed to in the ED.

Table 3. Statistical results of the resources of ED

\begin{tabular}{|c|c|c|c|c|c|c|c|}
\hline & \multirow{2}{*}{ Status* } & \multicolumn{3}{|c|}{ The Number of Patients Treated } & \multicolumn{3}{|c|}{ Waiting Time of the Patients } \\
\hline & & F-Value & P-Value & Status** & F-Value & P-Value & Status** \\
\hline$P$ & \multirow{5}{*}{ Individual } & 3523.56 & 0.001 & $\operatorname{Sig}(p<0.05)$ & 222.07 & 0.002 & $\operatorname{Sig}(p<0.05)$ \\
\hline $\mathrm{N}$ & & 2105.26 & 0.001 & Sig $(p<0.05)$ & 409.58 & 0.001 & Sig $(p<0.05)$ \\
\hline C & & 1.46 & 0.230 & Not Sig & 0.92 & 0.341 & Not Sig \\
\hline ER & & 685.89 & 0.001 & $\operatorname{Sig}(p<0.05)$ & 239.07 & 0.001 & $\operatorname{Sig}(p<0.05)$ \\
\hline $\mathrm{T}$ & & 0.93 & 0.337 & Not Sig & 2.31 & 0,131 & Not Sig \\
\hline$P * N$ & \multirow{10}{*}{$\begin{array}{c}\text { 2-Way } \\
\text { Interactions }\end{array}$} & 261.05 & 0.001 & $\operatorname{Sig}(p<0.05)$ & 6.05 & 0.001 & $\operatorname{Sig}(p<0.05)$ \\
\hline $\mathrm{P}^{*} \mathrm{C}$ & & 5.40 & $0.060 * \star \star$ & Provisionally Sig & 0.70 & 0.499 & Not Sig \\
\hline$P * E R$ & & 159.73 & 0.001 & $\operatorname{Sig}(p<0.05)$ & 45.98 & 0.001 & $\operatorname{Sig}(p<0.05)$ \\
\hline$P * T$ & & 38.20 & 0.001 & $\operatorname{Sig}(p<0.05)$ & 12.34 & 0.001 & Sig $(p<0.05)$ \\
\hline$N^{*} \mathrm{C}$ & & 12.95 & 0.001 & $\operatorname{Sig}(p<0.05)$ & 3.73 & 0.027 & $\operatorname{Sig}(p<0.05)$ \\
\hline$N * E R$ & & 34.22 & 0.001 & Sig $(p<0.05)$ & 37.36 & 0.001 & $\operatorname{Sig}(p<0.05)$ \\
\hline$N * T$ & & 24.50 & 0.001 & Sig $(p<0.05)$ & 6.43 & 0.002 & Sig $(p<0.05)$ \\
\hline$C * E R$ & & 13.14 & 0.001 & Sig $(p<0.05)$ & 6.85 & 0.002 & Sig $(p<0.05)$ \\
\hline $\mathrm{C} * \mathrm{~T}$ & & 0.58 & 0.446 & Not Sig) & 0.17 & 0.679 & Not Sig) \\
\hline$E R * T$ & & 362.41 & 0.001 & $\operatorname{Sig}(p<0.05)$ & 81.16 & 0.001 & Sig $(p<0.05)$ \\
\hline$P * N * C$ & \multirow{10}{*}{$\begin{array}{c}\text { 3-Way } \\
\text { Interactions }\end{array}$} & 11.70 & 0.001 & $\operatorname{Sig}(p<0.05)$ & 1.63 & 0.173 & Not Sig \\
\hline$P * N * E R$ & & 43.40 & 0.001 & $\operatorname{Sig}(p<0.05)$ & 15.79 & 0.001 & $\operatorname{Sig}(p<0.05)$ \\
\hline$P * N * T$ & & 28.29 & 0.001 & $\operatorname{Sig}(p<0.05)$ & 12.39 & 0.001 & Sig $(p<0.05)$ \\
\hline$P * C * E R$ & & 45.71 & 0.001 & $\operatorname{Sig}(p<0.05)$ & 4.74 & 0.001 & Sig $(p<0.05)$ \\
\hline$P * C * T$ & & 20.07 & 0.001 & $\operatorname{Sig}(p<0.05)$ & 4.14 & 0.019 & $\operatorname{Sig}(p<0.05)$ \\
\hline$P * E R * T$ & & 154.77 & 0.001 & $\operatorname{Sig}(p<0.05)$ & 9.23 & 0.001 & $\operatorname{Sig}(p<0.05)$ \\
\hline$N * C * E R$ & & 47.69 & 0.000 & $\operatorname{Sig}(p<0.05)$ & 2.68 & 0.035 & $\operatorname{Sig}(p<0.05)$ \\
\hline$N * C * T$ & & 13.92 & 0.000 & $\operatorname{Sig}(p<0.05)$ & 5.35 & 0.006 & $\operatorname{Sig}(p<0.05)$ \\
\hline$N * E R * T$ & & 55.00 & 0.002 & $\operatorname{Sig}(p<0.05)$ & 17.47 & 0.001 & $\operatorname{Sig}(p<0.05)$ \\
\hline$C \star E R * T$ & & 35.65 & 0.001 & Sig $(p<0.05)$ & 1.33 & 0.268 & Not Sig \\
\hline$P * N * C * E R$ & \multirow{5}{*}{$\begin{array}{c}\text { 4-Way } \\
\text { Interactions }\end{array}$} & 15.55 & 0.000 & $\operatorname{Sig}(p<0.05)$ & 1.08 & 0.380 & Not Sig \\
\hline$P * N * C * T$ & & 8.78 & 0.001 & Sig $(p<0.05)$ & 0.62 & $0.0646^{\star \star \star}$ & Provisionally Sig \\
\hline$P * N * E R * T$ & & 245.94 & 0.000 & Sig $(p<0.05)$ & 26.24 & 0.001 & $\operatorname{Sig}(p<0.05)$ \\
\hline$P \star C * E R * T$ & & 81.05 & 0.001 & $\operatorname{Sig}(p<0.05)$ & 1.36 & 0.252 & Not Sig \\
\hline$N^{*} C^{*} E R^{*} T$ & & 42.92 & 0.002 & Sig $(p<0.05)$ & 8.90 & 0.001 & Sig $(p<0.05)$ \\
\hline$P^{*} N^{*} C^{*} E R^{\star} T$ & $\begin{array}{c}\text { 5-Way } \\
\text { Interactions }\end{array}$ & 41.41 & 0.002 & Sig $(p<0.05)$ & 4.60 & 0.001 & Sig $(p<0.05)$ \\
\hline
\end{tabular}

Note: * to determine the individual and interactive effects of the factors that could affect the response and ${ }^{* *}$ statistically significant ( $p$-value $\left.<0.05\right), * * *$ at the margin of statistical significance, 
The number of physicians, nurses and exam rooms has significant effects on decreasing the waiting time. It has been found that the number of clerks increases the waiting time with the increase of the triage area as well as the effect on the waiting time. That is, the number of physicians, nurses and treatment rooms has a positive effect whereas the effect of triage area is negative. The effect of the number of clerks seems to be neutral.

There are three cases of positive, negative and neutral decision variables that affect the number of patients treated as well. The number of physicians as defined decision variable is the most influential factor on the number of patients treated. In the same way, the number of nurses and exam rooms seem to have a positive effect on the number of patients treated. However, with the number of clerks and triage areas appears to be a neutral effect over the number of patients treated.

We aimed to increase the number of patients treated and minimize the waiting time for patients to be treated constitutes the objective functions of this study. The average waiting time of a patient in the ED was reduced from 10.75 minutes to 9.83 minutes (improvement of $9.36 \%$ ), resulting in a significant result. Currently, the number of patients treated daily is 132 people. Based on the results of the combination of all sources, an average of 68 patients were treated. However, as a result of the improvement, the number of patients treated increased to 147 . This resulted in an improvement of $11.36 \%$ based on the average number of treated patients and a $116.176 \%$ percent improvement over the number of treated patients according to the use of all available resources (see Table 4).

Table 4. The values of the factors for the waiting time and the number of patients treated

\begin{tabular}{ccc}
\hline Factors & Waiting Time & Patients Output \\
\hline $\mathrm{P}$ & 3.00 & 3.00 \\
$\mathrm{~N}$ & 2.00 & 3.00 \\
\hline $\mathrm{C}$ & 2.00 & 2.00 \\
\hline $\mathrm{T}$ & 1.00 & 1.00 \\
\hline $\mathrm{ER}$ & 3.00 & 2.00 \\
\hline Optimum Value & $9.83221 \mathrm{~min}$ & $146.5 \simeq 147$ \\
\hline Current State Value & $10.75 \mathrm{~min}$ & $131.5 \simeq 132$ \\
\hline Average Value & $40.09 \mathrm{~min}$ & $67.39 \simeq 67$ \\
\hline Improvement & $9.36 \%$ & $11.36 \%$ \\
\hline Improvement & & $116.76 \%$ \\
\hline
\end{tabular}

Note: ${ }^{+}$The results based on the current situation, and ${ }^{++}$The results based on average of data

\section{CONCLUSIONS}

In this paper, we presented an efficient method is DOE interaction of DES model for the healthcare. Providing high reliability has resulted for the optimum values by integrating the DOE approach with the DES technique. The method was presented in an illustrative case study alongside theoretical term. It is very difficult to get accurate results everywhere where the human factor is. The method developed allows to derivate scenarios for applications of healthcare that are difficult and costly to implement in real life to be made in a short time and at a low cost.

Initially, a DES model of the planned system for ED was created by using Flexsim healthcare software in this study. By integrating the DOE approach with the DES technique, the average waiting time of a patient in the hospital was reduced from 40.09 minutes to 9.83 minutes (improvement of $75.480 \%$ ), resulting in a significant result. The number of patients treated is increased from $131.5 \simeq 132$ (average) to $146.5 \simeq 147$ (improvement of $11.37 \%$ ) by increasing the capacity of resources without increasing the number of available resources for any part of the hospital in one day. With these results, the number of patients 
treated was increased, and the waiting time became shorter through having high utilization rate of healthcare's resources. In this way, patient satisfaction is increased.

\section{REFERENCES}

Ahmed, M.A. and Alkhamis, T.M. (2009), "Simulation optimization for an emergency department healthcare unit in Kuwait", European Journal of Operational Research, Vol. 198, No. 3, pp. 936-42.

Altiok, T. and Melamed, B. (2007), Simulation Modeling and Analysis with Arena. 1st ed. Academic Press, Cambridge.

Antony, J. (2003), Design of Experiments for Engineers and Scientists. Elsevier, USA.

Atalan, A. (2014) , “Central composite design optimization using computer simulation approach", Flexsim Quarterly Publication, pp. 5-19. available at: https://www.flexsim.com/wpcontent/uploads/2014/07/July2014.pdf (accessed 9 May 2019).

Atalan, A. (2018), “Türkiye saðlýk ekonomisi için ýstatistiksel çok amaçlý optimizasyon modelinin uygulanmasý", Ýpletme Ekonomi ve Yönetim Araptýrmalarý Dergisi, Vol. 1, No. 1, pp. 34-51. available at: http://dergipark.gov.tr/download/article-file/414076 (accessed 9 May 2019).

Atalan, A. (2019), "The impacts of healthcare resources on services of emergency department: discrete event simulation with box-behnken design', Ponte Academic Journal, Vol. 75, No. 6, pp. 12-23. http://dx.doi.org/10.21506/j.ponte.2019.6.10.

Atalan, A. (2020), "Forecasting for healthcare expenditure of Turkey Covering the years of 2018-2050", Gümüphane Üniversitesi Saðlýk Bilimleri Dergisi, Vol. 9, No. 1, pp. 8-16. http://dx.doi.org/10.37989/gumussagbil.538111.

Atalan, A. and Donmez, C. (2019), "'Employment of emergency advanced nurses of turkey: a discreteevent simulation application", Processes, Vol. 7, No. 1, pp. 48. http://dx.doi.org/10.3390/pr7010048.

Baesler, F.F. and Sepúlveda, J.A. (2001), "Multi-objective simulation optimization for a cancer treatment center", in Proceedings of the 2001 Winter Simulation Conference, IEEE, USA. http://dx.doi.org/10.1109/WSC.2001.977367.

Barton, R.R. (2001), "Designing simulation experiments", in Proceedings of the 2001 Winter Simulation Conference, IEEE, USA.

Bates, R.A., kenett, R., Steinberg, D.M. et al. (2006), "Achieving robust design from computer simulations", Quality Technology \& Quantitative Management, Vol. 3, No. 2, pp. 161-77.

Buxton, J.N. and Laski, J.G. (1962), "Control and simulation language", The Computer Journal, Vol. 5, No. 3, pp. 194-9.

Cabrera, E., Taboada, M., MI, I. et al. (2011), "Optimization of healthcare emergency departments by agent-based simulation", Procedia Computer Science, Vol. 4, pp. 1880-9.

Deb, K. and Kalyanmoy, D. (2001), Multi-Objective Optimization Using Evolutionary Algorithms. John Wiley \& Sons, Inc., New York, NY.

Ding, R., Lin, D.K.J. and Wei, D. (2004), "Dual-response surface optimization: a weighted MSE approach", Quality Engineering, Vol. 16, No. 3, pp. 377-85.

Dinh, M., Walker, A., Parameswaran, A. et al. (2012), "Evaluating the quality of care delivered by an emergency department fast track unit with both nurse practitioners and doctors", Australasian Emergency Nursing Journal, Vol. 15, No. 4, pp. 188-94. http://dx.doi.org/10.1016/J.AENJ.2012.09.001.

Eriksson, L., Johansson, E., Kettaneh- Wold, N. et al. (2001), Design of Experiments: Principles and Applications. Umetrics Academy, New York, NY.

Fisher, R.A. (1971), The Design of Experiment. Reprinted. Hafner Publishing Company, New York, NY.

Günal, M.M. and Pidd, M. (2010), "Discrete event simulation for performance modelling in health care: a review of the literature", Journal of Simulation, Vol. 4, No. 1, pp. 42-51. http://dx.doi.org/10.1057/jos.2009.25.

Hoyt, W.T., Leierer, S.J. and Millington, M. (2014), "Analysis and interpretation of findingsusing multiple regression techniques", Rehabilitation Counseling Bulletin, Vol. 49, No. 4, pp. 223-33.

Kelton, W.D. (2004), Simulation with Arena. 4th ed. WCB/McGraw-Hill, Boston. 
Kelton, W.D. and Barton, R.R. (2003), "Experimental design for simulation", in Proceedings of the 2003 Winter Simulation Conference, IEEE, USA.

Khuri, A.I. and Mukhopadhyay, S. (2010), "Response Surface Methodology", WIREs Computational Statistics, Vol. 2, No. 2, pp. 128-50.

Law, A.M. (2014), "A tutorial on design of experiments for simulation modeling", in Proceedings of the 2014 Winter Simulation Conference, IEEE, USA, pp. 66-80.

Lin, C.-I. (2008), Optimization Models for Capacity Planning in Health Care Delivery. University of Florida.

Montevechi, J.A.B., Pinho, A.F. and Leal, F. (2007), "Application of design of experiments on the simulation of a process in an automotive industry", in Proceedings of the 2007 Winter Simulation Conference, IEEE, USA, pp. 1601-9.

Mosadeghrad, A.M. (2014), "Factors influencing healthcare service quality", International Journal of Health Policy and Management, Vol. 3, No. 2, pp. 77-89.

Myers, R.H., Montgomery, D.C. and Anderson-Cook, C.M. (2016), Response Surface Methodology Process and Product Optimiztion Using Designed Experiment. 4th ed., Wiley-Blackwell, Hoboken, Wiley Series in Probability and Statistics.

Oehlert, G.W. (2010), A First Course in Design and Analysis of Experiments. University of Minnesota, Minneapolis.

Park, G.J., Lee, T.-H., Lee, K. H. et al. (2006), "Robust Design: an Overview", AlAA Journal, Vol. 44, No. 1, pp. 181-91.

Pidd, M. (2004), Computer Simulation in Management Science. 5th ed. Wiley, Hoboken.

Plath, S.J., Bratby, J.A., Poole, L., et al. (2018), "Nurse practitioners in the emergency department: Establishing a successful service", Collegian, Vol. 26, No. 4, pp. 457-62. http://dx.doi.org/10.1016/J.COLEGN.2018.11.005.

Salway, R., Valenzuela, R., Shoenberger, J. M. et al. (2017), “Emergency department (ED) overcrowding: evidence-based answers to frequently asked questions", Revista Médica Clínica Las Condes, Vol. 28, No. 2, pp. 213-9. http://dx.doi.org/10.1016/J.RMCLC.2017.04.008.

Unwin, M., Kinsman, L. and Rigby, S. (2016), "Why are we waiting? Patients' perspectives for accessing emergency department services with non-urgent complaints", International Emergency Nursing, Vol. 29, pp. 3-8. http://dx.doi.org/10.1016/J.IENJ.2016.09.003.

Authors contribution: A. Atalan: data collection, conceptualization, methodology, visualization, software, validation, writing-original draft preparation, C.C. Dönmez: Conceptualization, validation, writing-reviewing and editing. 